Available online at GSC Online Press Directory

GSC Biological and Pharmaceutical Sciences

e-ISSN: 2581-3250, CODEN (USA): GBPSC2

Journal homepage: https://www.gsconlinepress.com/journals/gscbps

(RESEARCH ARTICLE)

\title{
Phytochemical analysis and antibacterial activity of Psidium guajava L. leaf extracts
}

\author{
Ekeleme Kenneth, Tsaku Paul *, Nkene Istifanus, Ufomadu Uba, Abimiku Rejoice, Oti Victor and Sidi \\ Mohammed
}

Department of Microbiology, Nasarawa State University, PMB 1022, Keffi, Nigeria

Publication history: Received on 25 September 2017; revised on 30 October 2017; accepted on 08 November 2017

https://doi.org/10.30574/gscbps.2017.1.2.0024

\begin{abstract}
The increasing menace of antimicrobial resistance in many pathogenic microbes has led to the search for long lasting remedy. The aim of this study was to examine the phytochemical and antimicrobial properties of extracts of Psidium guajava leaves against some clinical bacterial isolates. The plant leaves were extracted in three solvents namely; water, ethanol and methanol. The pathogenic bacterial isolates were Pseudomonas aeruginosa, Escherichia coli, Staphylococcus aureus, Streptococcus pneumoniae and Klebsiella pneumoniae all isolated from urine samples. The phytochemical analysis showed the presence tannins, flavonoids, alkaloids, saponins, glycosides and terpenoids in different proportions. The mean antibacterial activity of the extracts in vitro showed that the ethanolic extract was most efficacious at $25 \mathrm{mg}$ concentration, inhibiting P. aeruginosa $(9.50 \mathrm{~mm})$, E. coli $(9.00 \mathrm{~mm})$, S. pneumoniae $(10.50$ $\mathrm{mm})$ and $K$. pneumoniae $(9.50 \mathrm{~mm})$. The aqueous extract at $100 \mathrm{mg}$ concentration inhibited E. coli $(12.50 \mathrm{~mm}), S$. aureus $(14.50 \mathrm{~mm})$ and $S$. pneumoniae $(9.00 \mathrm{~mm})$. This study has revealed that the leaves extract of $P$. guajava contains antibacterial and phytochemical substances which can be harnessed in satiation of human quest for better and healthier living.
\end{abstract}

Keywords: Psidium guajava; Plant extracts; Phytochemical; Antibacterial activity

\section{Introduction}

The continuous evolution of multidrug resistant pathogens is a global clinical concern [1-3]. In recent years there has been an increasing incidence of multiple drug resistance in human pathogenic microorganisms due to the indiscriminate uses of commercial antimicrobial drugs commonly employed in the treatment of infectious diseases [45]. This has led to the increase in search and research for new antimicrobial substances from various sources like medicinal plants. The search for new antibacterial agents by the screening of many plant families is encouraged [6-7]. Additionally, using antibiotics is sometime associated with adverse effects [8-9]. Therefore, phytomedicine could be an alternative treatment method for bacterial infections which may decrease such problems [9].

Psidium guajava is a fruit bearing plant commonly known as guava, which belongs to the family Myrtaceae [4]. Guava grows nearly throughout Nigeria up to $1500 \mathrm{~m}$ height and is cultivated commercially in some regions. The plant is described by its particular thin, smooth, copper hued bark that fragments off, demonstrating a greenish layer underneath. Guava trees have spread generally all through the tropics since they flourish in a variety of soils, easily propagating and bearing fruits rapidly. The fruits are appreciated by fowls and monkeys, which scatter the seeds and makes natural dumps of guava saplings to cultivate all over the rainforest [10].

\footnotetext{
${ }^{*}$ Corresponding author

E-mail address: tsakupaul@ gmail.com
}

Copyright (C) 2017 Author(s) retain the copyright of this article. This article is published under the terms of the Creative Commons Attribution Liscense 4.0. 
The leaves and bark of guava tree have a long history of medicinal uses. Decoction of the leaves and bark of guava is used to cure diarrhoea, dysentery, vomiting, sore throats and also to regulate menstrual cycles. The tribes of the Africa uses leaf decoction for mouth sores, bleeding gums, as douche for vaginal discharges and to tighten and tone up vaginal walls after labour. They are also an excellent source of fibre, potassium and retinoic acid [11].

Psidium guajava is a phytotherapic plant used in folk medicine and is believed to have active components that helps in treatment and management of various diseases [12]. Guava has exhibited remarkable antimicrobial activity against microorganisms such as Bacillus, E. coli, Staphylococcus, Pseudomonas, Clostridium, Shigella, Salmonella and yeast such as Candida species [13]. This study investigates the phytochemical and antibacterial properties of Psidium guajava L. leaf extracts.

\section{Material and methods}

\subsection{Collection of Samples and Preparation}

Fresh and healthy leaves of P. guajava L. were obtained at locations within Nasarawa state, North-Central Nigeria and identified at the Plant Science and Biotechnology herbarium in Nasarawa State University, Keffi. The leaves were washed in distilled water and allowed to dry at room temperature for 7 days. The leaves were then pulverized into coarse powder using blending machine.

\subsection{Isolation and Identification of Bacterial Species}

Bacterial species were isolated from urine samples of urinary tract infected (UTI)patients referred to the Microbiology Laboratory Unit of Federal Medical Centre, Keffi, Nigeria.The urine samples were cultured by streaking on Eosin Methylene Blue (EMB), MacConkey Agar (MA) and Mannitol Salt Agar (MSA), and incubated at $37^{\circ} \mathrm{C}$ for $24 \mathrm{hrs}$.

Identification of the bacterial isolates was based on the cultural and morphological and biochemical characteristics such as, Indole, Methyl Red/Vorges-Proskauer, Citrate utilization, Catalase, Coagulase, Nitrate reduction, Urease and Sugar fermentation tests following standard microbiological procedures as described by Cheesebrough [14] .

\subsection{Extraction of Psidium guajava leaves}

Extracts were prepared following the method described by S'anchez et al. [15]. Briefly, $100 \mathrm{~g}$ of dried pulverized guava leaves were soaked in $500 \mathrm{~mL}$ of water, methanol and ethanol for $24 \mathrm{hrs}$ at room temperature, under occasional shaking. Extraction was repeated three times, and the extracts obtained were filtered using Whatman filter paper number 1 . After that, the extracts were concentrated to dryness under reduced pressure using a rotary evaporator at $45^{\circ} \mathrm{C}$.

\subsection{Phytochemical Analysis}

\subsubsection{Test for Alkaloids}

The extracts $(20 \mu \mathrm{L})$ was applied on TLC plate (Silica Gel 60G, $5 \times 10 \mathrm{~cm}$ ) and eluted using toluene-ethyl acetatediethylamine (70: 20: 10) as solvent system. Alkaloid was detected after spraying Dragendorff's reagent as orangebrown spots on the TLC plate [16].

\subsubsection{Test for Quinones}

Extracts suspended in ethanol $(1 \mathrm{~mL})$ were treated with $1 \mathrm{~mL}$ of concentrated sulfuric acid. Formation of red colour showed the presence of quinones [17].

\subsubsection{Test for Glycosides}

One $\mathrm{ml}$ of glacial acetic acid, 3 drops $5 \% \mathrm{~W} / \mathrm{V}$ ferric chloride and concentrated sulphuric acid were added to test tubes containing $2 \mathrm{ml}$ of extracts and observed. The disappearance of reddish brown colour at the junction of two layers and bluish green in upper layer indicates the presence of glycosides [18].

\subsubsection{Test for Tannins}

Extracts were treated with $1 \mathrm{~mL}$ of $5 \%$ ferric chloride. The presence of tannin was indicated by the formation of bluish black or greenish black precipitate [19]. 


\subsubsection{Test for flavonoids}

Few fragments of magnesium metal ribbon (3-4 pieces) was added to $1 \mathrm{~mL}$ of the extracts, followed by drop wise addition of concentrated hydrochloric acid. Formation of pink or red colour indicated the presence of flavonoids [20].

\subsubsection{Test for Saponin}

The $2 \mathrm{~mL}$ of distilled water was added to extracts suspended in ethanol and was shaken vigorously. The formation of profuse foam layer indicated the presence of saponins [20].

\subsubsection{Test for Terpenoids}

One $\mathrm{mL}$ of acetic anhydride and 5 drops of concentrated sulfuric acid $\left(\mathrm{H}_{2} \mathrm{SO}_{4}\right)$ was added to the extracts.A colour change from violet to blue confirms the presence of steroids [21] and formation of blue-green ring indicates the presence of terpenoids [22].

\subsection{Determination of Antibacterial Activity of Psidium guajava leaves}

Antibacterial activity of crude extracts (aqueous, methanol and ethanol) of P. guajava leaves was carried out using cup-plate agar diffusion bioassay [23] as follows; $100 \mu \mathrm{L}$ of fresh culture (Standardized to $0.5 \mathrm{McFarland}$ ) was spread uniformly on a sterile Mueller-Hinton agar (MHA) plates and allowed to air dry. After that, wells of $6 \mathrm{~mm}$ in diameter were made in the MHA plates using a sterilized cup-borer and the base was seeded with molten MHA and approximately $100 \mu \mathrm{L}$ for each concentration $(50 \mathrm{mg} / \mathrm{L}, 25 \mathrm{mg} / \mathrm{L}, 12.5 \mathrm{mg} / \mathrm{L}, 6.25 \mathrm{mg} / \mathrm{L}, 3.125 \mathrm{mg} / \mathrm{L}, 1.56 \mathrm{mg} / \mathrm{L}$ and $0.78 \mathrm{mg} / \mathrm{L}$ ) of the extract was dispensed into the wells and the plates were allowed to stand for $1 \mathrm{hr}$ at room temperature for pre-diffusion and then incubated at $37^{\circ} \mathrm{C}$ for $24 \mathrm{hrs}$ and the diameter zone of inhibition against the test strain is measured and recorded. Ciprofloxacin $(5 \mu \mathrm{g})$ was used as control.

\section{Results and discussion}

The qualitative screening of phytochemical properties of P.guajava leaves extracts showed the presence of moderate quantities (+) and large quantities of tannins, alkaloids, saponins, glycoside, terpenoids, and flavonoids in the different solvents used (Table 1).

Table 1 Phytochemical test on solvent fractions of $P$. guajava leaves extracts

\begin{tabular}{lllllll}
\hline Fractions & Tannins & Flavonoids & Alkaloids & Saponins & Glycoside & Terpenoids \\
\hline Ethanol & + & ++ & + & - & - & + \\
Methanol & ++ & ++ & - & + & + & + \\
Aqueous & ++ & + & + & + & + & + \\
\hline \multicolumn{7}{c}{ - =Absent; + = Present in moderate quantity; ++ = Present in large quantity }
\end{tabular}

The antibacterial activity of crude ethanol extracts of P. guajava against clinical bacterial isolates (Table 2) showed that the ethanolic extracts has antibacterial activity at concentrations $25 \mathrm{mg}$ above against all tested bacteria with the exception of $S$. aureus which was inhibited only at $50 \mathrm{mg}$ concentration. Table 3 showed the antibacterial activity of crude methanolic extract of leaves of $P$. guajava against clinical bacterial isolates. In the results, the highest inhibitory activity was observed against $K$. pneumoniae where $16.5 \mathrm{~mm}$ mean zone of inhibition was observed at $50 \mathrm{mg}$ concentration. E. coli was mostly resistant to this extract and only showed $1.0 \mathrm{~mm}$ mean zone of inhibition at $50 \mathrm{mg}$ concentration. The antibacterial activity of crude aqueous leaves extract of P. guajava against clinical bacterial isolates (Table 3) showed significant level of activity against all test bacterial isolates at $100 \mathrm{mg}$ concentration with decreased activity at lower concentrations. 
Ekeleme et al. / GSC Biological and Pharmaceutical Sciences 2017, 01(02), 013-019

Table 2 Antibacterial activity of crude ethanol extract of P. guajava leaves against clinical bacteria isolates

\begin{tabular}{|c|c|c|c|c|c|c|c|}
\hline \multirow[t]{2}{*}{ Bacterial isolates } & \multicolumn{7}{|c|}{ Diameter zone of inhibition (mm) } \\
\hline & $50 \mathrm{mg}$ & $25 \mathrm{mg}$ & $12.5 \mathrm{mg}$ & $6.25 \mathrm{mg}$ & $3.125 \mathrm{mg}$ & $1.56 \mathrm{mg}$ & $0.75 \mathrm{mg}$ \\
\hline P. aeruginosa & $12.5 \pm 0.71$ & $9.5 \pm 0.78$ & 0.00 & 0.00 & 0.00 & 0.00 & 0.00 \\
\hline E. coli & $16.0 \pm 1.41$ & $9.0 \pm 1.41$ & 0.00 & 0.00 & 0.00 & 0.00 & 0.00 \\
\hline S. aureus & $10.0 \pm 0.74$ & 0.00 & 0.00 & 0.00 & 0.00 & 0.00 & 0.00 \\
\hline S. pneumoniae & $12.0 \pm 1.43$ & $10.5 \pm 2.10$ & 0.00 & 0.00 & 0.00 & 0.00 & 0.00 \\
\hline K. pneumoniae & $11.5 \pm 0.77$ & $9.5 \pm 0.72$ & 0.00 & 0.00 & 0.00 & 0.00 & 0.00 \\
\hline
\end{tabular}

Table 3 Antibacterial activity of crude methanolic extract of P. guajava leaves against clinical bacteria isolates

\begin{tabular}{|c|c|c|c|c|c|c|c|}
\hline \multirow{2}{*}{$\begin{array}{l}\text { Bacterial } \\
\text { isolates }\end{array}$} & \multicolumn{7}{|c|}{ Diameter zone of inhibition (mm) } \\
\hline & $50 \mathrm{mg}$ & $25 \mathrm{mg}$ & $12.5 \mathrm{mg}$ & $6.25 \mathrm{mg}$ & $3.125 \mathrm{mg}$ & $1.56 \mathrm{mg}$ & $0.75 \mathrm{mg}$ \\
\hline P. aeruginosa & $14.0 \pm 1.51$ & $10.5 \pm 1.55$ & $7.5 \pm 0.87$ & 0.00 & 0.00 & 0.00 & 0.00 \\
\hline E. coli & $1.0 \pm 1.51$ & 0.00 & 0.00 & 0.00 & 0.00 & 0.00 & 0.00 \\
\hline S. aureus & $14.0 \pm 1.51$ & $10.0 \pm 1.45$ & 0.00 & 0.00 & 0.00 & 0.00 & 0.00 \\
\hline S. pneumonia & $11.0 \pm 1.61$ & 0.00 & 0.00 & 0.00 & 0.00 & 0.00 & 0.00 \\
\hline K. pneumoniae & $16.5 \pm 1.71$ & $9.5 \pm 0.45$ & $5.6 \pm 0.58$ & 0.00 & 0.00 & 0.00 & 0.00 \\
\hline
\end{tabular}

Table 4 Antibacterial activity of crude aqueous extracts of $P$. guajava leaves against clinical bacteria isolates

\begin{tabular}{lccccccc}
\hline \multirow{2}{*}{$\begin{array}{c}\text { Bacterial } \\
\text { isolates }\end{array}$} & \multicolumn{7}{c}{ Diameter zone of inhibition (mm) } \\
\cline { 2 - 8 } & $\mathbf{5 0} \mathbf{~} \mathbf{~ g ~}$ & $\mathbf{2 5} \mathbf{~ m g}$ & $\mathbf{1 2 . 5} \mathbf{~ m g}$ & $\mathbf{6 . 2 5} \mathbf{~ m g}$ & $\mathbf{3 . 1 2 5} \mathbf{~} \mathbf{~ g}$ & $\mathbf{1 . 5 6} \mathbf{~ m g}$ & $\mathbf{0 . 7 5} \mathbf{~ m g}$ \\
\hline P. aeruginosa & $18.0 \pm 1.51$ & $10.5 \pm 1.55$ & $5.5 \pm .87$ & 0.00 & 0.00 & 0.00 & 0.00 \\
E. coli & $12.5 \pm 2.11$ & 0.00 & 0.00 & 0.00 & 0.00 & 0.00 & 0.00 \\
S. aureus & $14.5 \pm 0.69$ & $14.5 \pm 1.45$ & 0.00 & 0.00 & 0.00 & 0.00 & 0.00 \\
S. pneumonia & $12.0 \pm 1.45$ & $9.0 \pm 1.42$ & 0.00 & 0.00 & 0.00 & 0.00 & 0.00 \\
K. pneumonia & $12.5 \pm 1.71$ & $16 \pm 1.67$ & $5.6 \pm 0.58$ & 0.00 & 0.00 & 0.00 & 0.00 \\
\hline \multicolumn{7}{c}{ Results expressed as mean \pm SD }
\end{tabular}

This study on the phytochemical and antimicrobial properties of $P$. guajava leaves extracts on clinical bacterial isolates using alcoholic solvents (ethanol and methanol) and water revealed that the ethanolic extracts inhibits $P$. aeruginosa, E. coli, S. pneumoniae, and K. pneumoniae at $25 \mathrm{mg}$ concentration whereas S. aureus was inhibited at $50 \mathrm{mg}$ concentration of the ethanolic extracts. However, the methanolic extracts was potent at 12.5 mg concentration against $P$. aeruginosa and K. pneumoniae, while the aqueous extract was potent at $25 \mathrm{mg}$ and above against tested bacterial isolates. Fugaban [13] has reported that the alcoholic extract of P. guajava leaves have antimicrobial activity against the fungus Tricophyton metagrophytes. Pandey et al. [12] has also demonstrated the antifungal properties of $P$. guajava leaves extracts. In line with this research report also, Biswas et al. [24] has reported that P. guajava has Gram-negative and Gram-positive antibacterial characteristics.

This research has also demonstrated the presence of alkaloids, flavonoids, tannins, saponins, glycosides and terpenoids in the leaves extracts of P. guajava. Also, these phytochemicals has been shown to have inhibitory activity against some clinical bacterial isolates in vitro. Reports have been made on the use of plants for therapeutic purposes dating back to centuries before the advent of antibiotics. The cinchona plant has been reportedly used to treat malaria [25-26]. Since microorganisms have become increasingly resistant to available antibiotics, scientists have been exploring various sources, including plants, to remediate the menace of antimicrobial resistance. 
In recent years, reports on the antimicrobial and phytochemical properties of different plants have been published $[12-13,27-33]$. This research result is believed to contribute in a way as humans continue to source for total cure for infectious diseases especially with the growing trends of antimicrobial resistivity.

\section{Conclusion}

The phytochemicals and antimicrobial studies of P. guajava leaf extracts provided scientific evidence for the rationale use of $P$. guajava leaves in prevention of disorders due to presence of some useful phytochemicals, and in treatment of diseases caused by some bacterial pathogens such as P. aeruginosa, E. coli, S. aureus, S. pneumoniae and K. pneumoniae. Further research is necessary to reveal its detailed molecular mechanism behind these phytochemical and antibacterial activities.

\section{Compliance with ethical standards}

\section{Acknowledgments}

The researchers acknowledge the contribution of the staffs of Microbiology Department and Biological Sciences Department of Nasarawa State University, Keffi, Nigeria.

\section{Disclosure of conflict of interest}

Authors have declared that no competing interests exist.

\section{References}

[1] Poole K. (2005). Efflux-mediated antimicrobial resistance. Journal of Antimicrobial Chemotherapy, 56, $20-51$.

[2] Nikaido H. (2009). Multidrug resistance in bacteria. Annual Review of Biochemistry, 78, 119-146.

[3] Pourahmad JR. and Jazayeri N. (2013). Expression of acrA and acrB genes in Esherichia coli mutants with or without marR or acrR mutations. Iranian Journal of Basic Medical Sciences, 16, 1254-1258.

[4] Qa'dan F, Thewaini A, Ali D, Afifi A, Elkhawad RA and Matalka Z. (2005). The antimicrobial activities of Psidium guajava and Juglans regia leaf extracts to acne developing organisms. The American Journal of Chinese Medicine, 33 (2), 197-204.

[5] Tsaku PA, Ehinmidu JO and Mohammed SA. (2017). Antibiotic susceptibility and plasmid profile of Escherichia coli from door handles in two tertiary institutions in Nasarawa State, Nigeria. Journal of Advances in Microbiology, 3(3), 1-13.

[6] Begum S, Hassan SI and Siddiqui BS. (2007). Two new triterpenoids from the fresh leaves of Psidium guajava. Planta Medica, 68 (12), 1149-1152.

[7] Dipankar C. (2011). Review on medicinal pharmacological properties of Iresine herbstii, Chrozophora rottleri and Ecbolium linneanum. African Journal of Traditional Complementary and Alternative Medicines, 8(5), 124129.

[8] Barbosa TM and Levy SB. (2000). The impact of antibiotic use on resistance development and persistence. Drug Resistance Updates, 3, 303-311.

[9] Alekshun MN and Levy SB. (2007). Molecular mechanisms of antibacterial multidrug resistance. Cell, 128 (6), 1037-1050.

[10] Akiyama K, Matsuoka H and Hayashi H. (2002). Isolation and identification of a phosphate deficiency-induced C-glycosyl flavonoid that stimulates arbuscular mycorrhiza formation in melon roots. Molecular Plant-Microbe Interactions, 15(4), 334-340.

[11] Chanda S and Kaneria M. (2010). Indian nutraceutical plant leaves as a potential source of natural antimicrobial agents, in Science against Microbial Pathogens: Communicating Current Research and Technological Advances, Mendez-Vilas A. Ed., 2, 1251-1259.

[12] Pandey M, Qidwai A, Kumar R, Pandey A, Shukla SK, Pathak A and Dikshit A. (2017). Pharmacological and antibacterial aspect of Psidium guajava L against Acne vulgaris. International Journal of Pharmaceutical Sciences and Research, 8(1), 145-150. 
[13] Fugaban HC. (2016). Comparative study on antifungal property of methanolic and ethanolic extracts of Psidium guajava on Trichophyton mentagrophytes. Scholars Academic Journal of Biosciences, 4 (2), 158-160.

[14] Cheesbrough M. (2006). Biochemical testing of microorganism. Medical Laboratory Manual for Tropical Countries. Vol. II.

[15] S'anchez E, Heredia N and Garc'ia S. (2010). Extracts of edible and medicinal plants damage membranes of Vibrio cholerae. Applied and Environmental Microbiology, 76 (20), 6888-6894.

[16] Wagner H and Bladt S. (2001). Plant Drug Analysis. A Thin Layer Chromatography Atlas. Springer, New York, NY, USA.

[17] Dominguez XA. (1973). Methods in Research Fitok imica, LIMUSA.

[18] Tona L, Kambu K, Ngimbi N, Mesia K, Penge O, Lusakibanza M, Cimanga K, De Bruyne T, Apers S, Totte J and Pieters L. (2000). Antiamoebic and spasmolytic activities of extracts from some antidiarrhoeal traditional preparations used in Kinshasa, Congo. Phytomedicine, 7(1), 31-38.

[19] Firdouse S and Alam P. (2011). Phytochemical investigation of extract of Amorphophallus campanulatus tubers. International Journal of Phytomedicine, 3 (1), 32-35.

[20] Rathore S, Bhatt S, Dhyani S and Jain A. (2012). Preliminary phytochemical screening of medicinal plant Ziziphus mauritiana Lam fruits. International Journal of Current Pharmaceutical Research, 4 (3), 160-162.

[21] Boxi M, Rajesh Y, Kumar VR, Praveen B and Mangamma K. (2010). Extraction, phytochemical screening and invitro evaluation of anti-oxidant properties of Commicarpus chinesis (aqueous leaf extract). International Journal of Pharmaceutical and Biological Science, 1 (4), 547.

[22] Fawehinmi AB, Lawal H, Etatuvie SO and Oyedeji FO. (2013). Preliminary phytochemical screening and antimicrobial evaluation of four medicinal plants traditionally used in Nigeria for skin infection. African Journal of Pure and Applied Chemistry, 7(2), 44-49.

[23] Clinical and Laboratory Standards Institute (2012). Performance standards for antimicrobial susceptibility testing. CLSI 22 ${ }^{\text {nd }}$ Informational Supplement M100-S22. Wayne, PA, USA.

[24] Biswas B, Rogers K, McLaughlin F, Daniels D and Yadav A. (2013). Antimicrobial activities of leaf extracts of guava (Psidium guajava L.) on two gram-negative and gram-positive bacteria. International Journal of Microbiology, Article ID 746165, 7.

[25] Cowen JM. (1929). Cinchona in the Empire: progress and prospects of its cultivation. Empire Forestry Journal, 8 (1), 45-53.

[26] Poser CM and Bruyn GW. (1999). An illustrated history of malaria. Parthenon, New York.

[27] Thirunavukkarasu K, Ramanathan T, Ravichandranand N and Ramkumar L. (2010). Screening of antimicrobial effect in watermelon (Citrillus sp.). Journal of Biological Sciences, 10, 682-685.

[28] Farombi EO and Owoeye 0. (2011). Antioxidative and chemopreventive properties of Vernonia amygdalina and Garcinia biflavonoid. International Journal of Environmental Research and Public Health, 8(6), 2533-2555.

[29] Sekar M, Sutharesan N, Mashi DA, Shaiful MH, Shazni M, Wei KM, Istiazzul M and Abdullah MS. (2014). Comparative evaluation of antimicrobial properties of red and yellow watermelon seeds. International Journal of Current Pharmaceutical Research, 6(3), 35-37.

[30] Nessma AE. (2015). Antioxidant, antitumor, antimicrobial studies and quantitative phytochemical estimation of ethanolic extracts of selected fruit peels. International Journal of Current Microbiology and Applied Sciences, 4(5), 298-309.

[31] Egbuonu AC. (2015). Comparative investigation of the antibacterial and antifungal potentials of the extracts of watermelon (Citrullus lanatus) rind and seed. European Journal of Medicinal Plants, 9(4), 1-7.

[32] Chinmay D, Anurekha D, Mukul J and Tambe S. (2015). Phytochemical and pharmacological profile of Citrullus lanatus (THUNB). Biolife, 3(2), 483-488.

[33] Sánchez E, Morales R, Castillo S, Leos-Rivas C, García-Becerra L, Martínez D0. (2016). Antibacterial and antibiofilm activity of methanolic plant extracts against nosocomial microorganisms. Evidence-Based Complementary and Alternative Medicine, 2016, 1-8. 
Ekeleme et al. / GSC Biological and Pharmaceutical Sciences 2017, 01(02), 013-019

\section{How to cite this article}

Ekeleme K, Tsaku P, Nkene I, Ufomadu U, Abimiku R, Oti V and Sidi M. (2017). Phytochemical analysis and antibacterial activity of Psidium guajava L. leaf extracts. GSC Biological and Pharmaceutical Sciences, 1(2), 13-19. 